\title{
Politicians unleashed? Political communication on Twitter and in parliament in Western Europe
}

\author{
Bruno Castanho Silva* (D) and Sven-Oliver Proksch \\ Cologne Center for Comparative Politics, University of Cologne, Cologne, Germany \\ ${ }^{\star}$ Corresponding author. Email: bcsilva@wiso.uni-koeln.de
}

(Received 26 June 2020; revised 5 February 2021; accepted 25 February 2021; first published online 15 July 2021)

\begin{abstract}
Twitter is a prominent communication tool for politicians with two potential uses: as a "substitute" channel to circumvent constraints from other political arenas, or as an "amplifier" that reinforces party messages. Using a novel dataset containing tweets and parliamentary speeches by members of parliament (MPs) in seven countries, we estimate politicians' positions and intra-party dissent on European integration. We find that MPs' sentiment about Europe on Twitter is a valid measure of their party's position, while also uncovering intra-party disagreements. Our results suggest that most MPs amplify the partisan message, but MPs who participate less in parliamentary debate tend to have larger differences with their party on Twitter. Social media thus can free politicians from their party's grip.
\end{abstract}

Keywords: Text and content analysis; European politics and integration; legislative politics

Social media allows politicians across Europe to directly communicate with the public. Such political communication stands in stark contrast to the regulated debates in parliaments, in which time constraints and procedural rules limit the ability of individual MPs to express views on all issues. Yet, despite the two different arenas, it is unclear how social media platforms actually change the way in which politicians communicate or interact with their voters, or what new incentives and opportunities they present. The lingering question is if, and how, the usage of social media by politicians is different from communication in parliaments.

We investigate two central claims on the role of social media in politics, which we call "amplifier" and "substitute" channel hypotheses. The literature on parties and electoral institutions has highlighted the importance of unified political parties. MPs in parliamentary systems with strong parties have an inherent incentive to tout the party line, as the electoral success of their party enhances their own reelection prospects (e.g., Carey and Shugart, 1995; Sieberer, 2006; Carey, 2009; Kam, 2009). Moreover, there is evidence that parties try to enforce unity not only in legislative votes, but also during parliamentary debates by controlling the speaker selection process, if necessary (Proksch and Slapin, 2012, 2015). Along those lines, Twitter would serve as just another channel for parties to reach voters with the same message they put forward in other arenas. We consider this the amplifier mechanism.

On the other hand, parties are not always unified. One prominent example is the issue of European integration (Hobolt and de Vries, 2016): several mainstream parties across the continent see their members divided along pro- or anti-European positions, with a new cleavage that cuts across traditional party lines (Hooghe and Marks, 2018). Social media presents "a new tool for personal politics" (Enli and Skogerbø, 2013, p. 771), and studies of Twitter use by members of parliament (MPs) indicate that the follower network (Barberá, 2015) and content posted

(C) The Author(s), 2021. Published by Cambridge University Press on behalf of the European Political Science Association. This is an Open Access article, distributed under the terms of the Creative Commons Attribution licence (http://creativecommons.org/licenses/by/4.0/), which permits unrestricted re-use, distribution, and reproduction in any medium, provided the original work is properly cited. 
by MPs (Ecker, 2017) are informative not only about MP ideology, but also of intra-party dynamics such as party switching or candidate endorsement (Ceron, 2017; Sältzer, 2020). MPs could therefore have an incentive to choose Twitter to personalize their message and enhance their personal profile in cases where there is internal disagreement with the party line. For example, Euroskeptic MPs in mainstream pro-EU parties might face partisan constraints in other arenas, such as parliament, turning to social media to expose their ideas. In short, Twitter may serve as a substitute channel for political communication, circumventing partisan and institutional constrains.

We test these two perspectives by matching a dataset of tweets by all members of seven national parliaments in Europe over the course of 2018 from Castanho Silva and Proksch (2021) to 320,000 parliamentary speeches from the same politicians during the time. We focus on European integration, and use a sentiment approach to measure individual politicians' positions on Europe. Our validation efforts show the benefits of such an approach, while also highlighting some limitations given that estimating a fine-grained measure of policy positioning at the individual MP level is substantially more difficult than doing so at the party level. Nevertheless, for most cases, we are able to separate the signal from the noise, and thus present a way of measuring the positions of individual politicians in a comparable way across countries and languages. Substantively, we find that social media serves both theorized purposes of amplification and substitution, and that the substitute channel ultimately is a strong explanation for MPs' Twitter use when they disagree with their parties. First, in support of the amplifier mechanism, MPs' positions on Europe on Twitter reflect those of their parties, and those MPs for whom Europe is more salient also tweet more about this issue. Second, our results indicate that MPs who diverge from their party's EU position on Twitter tend to speak less in parliament, and appear to selfcensor their dissenting EU position when they do get to speak. The evidence indicates that, for some MPs, Twitter may constitute a promising substitute outlet.

\section{Political communication in social media}

To investigate political communication on Twitter and in parliament, we focus on the issue of European integration for three reasons: first, the incontrovertible increase in EU integration salience during national political campaigns in the EU (Hooghe and Marks, 2018), leading to greater incentives for national MPs to express positions on the issue generally. The issue dimension is similar in all EU countries, as parties take stances for or against deeper European integration, allowing for a comparative analysis. Second, it has sparked internal divisions in many parties. These divisions have emerged especially in the wake of the financial and refugee crises when new challenger and Euroskeptic parties have formed and competed against mainstream ones (Hobolt and de Vries, 2016; Hobolt and Tilley, 2016). ${ }^{1}$ Third, EU integration is an area in which the national executive dominates national policy-making, with little power yielded to national parliaments. Most communication done by national MPs on Europe is position-taking and signaling, making European integration an ideal topic to look for the relationship between rhetoric on Twitter and in parliament.

\subsection{Twitter as an amplifier}

A large body of research has found that parties' and politicians' use of online communication is timid: the dominant purpose is spreading news about themselves (Golbeck et al., 2010; Jackson and Lilleker, 2011), replicating messages from other platforms (Larsson, 2015), and signal

\footnotetext{
${ }^{1}$ Given that our goal is to identify MPs deviating from the party line, we need an issue in which we know that intra-party dissent actually occurs. The method we propose for measuring MPs' positions on EU integration based on tweets could be used to measure preferences on other, less divisive issues.
} 
issue positions (Kruikemeier, 2014). While social media offers much more opportunities for interaction with supporters, this is rarely seen (Theocharis et al., 2016). The reasoning for amplifying the party message through Twitter is reaching a larger audience, by communicating directly with politically interested followers (Diaz et al., 2016; Spierings and Jacobs, 2014), and count on indirect or accidental exposure, due to retweets and shares, to bring party communication to non-followers (Bode, 2016; Popa et al., 2020). Knowing the different audiences across different platforms, politicians and parties can emphasize different issues in each in order to better cater their message to each public (Jungherr et al., 2015; Kreiss, 2016; Stier et al., 2018). ${ }^{2}$ Nevertheless, while salience might vary according to topic, parties cannot entirely change their positions in relation to what is presented elsewhere. This use is what we term the "amplifier" aspect of Twitter. Parties and politicians go online to amplify the reach of the same message they already push in other arenas. In the context of European integration, our first two hypotheses are:

H1 Positions on European integration expressed in MPs' tweets reflect their party's EU position.

H2 Positions on European integration expressed in MPs' tweets reflect their own positions expressed in parliament.

Besides amplified position-taking, another way of amplifying a message is through an increase in issue salience. Politicians can adjust the topics they focus on across different arenas, adapting to a different public (Kreiss, 2016), but we can expect that the volume of their social media activity on a certain topic reflects the importance they attribute to it in their general discourse. Therefore, MPs for whom European integration is more salient would both tweet more about it, and talk more about Europe in parliament. Our second set of hypotheses, focusing on the amplification of salience, are:

H3 Politicians' frequency of tweeting about Europe is related to the salience their parties attribute to European integration.

H4 Politicians' frequency of tweeting about Europe is related to their frequency of talking about Europe in parliament.

\subsection{Twitter as a substitute}

We expect the amplifier mechanism delineated above to be the dominant, or baseline, mode of MPs' communication on social media. However, Twitter also provides opportunities for personalized campaigning beyond the party brand (Enli and Skogerbø, 2013). A main point of social media is expressing one's opinion on any issue with a feeling of being unrestrained (Schober et al., 2015), which may lead politicians to express opinions closer to their "true preferences". Before the advent of social media, any politician who wanted to send their message to voters would have to go through two potential gatekeepers: party leaders, keen on enforcing unity (Cox, 2006; Proksch and Slapin, 2012), and traditional media, which would not automatically give space to just any politician, in particular parliamentary backbenchers. The widespread use of social media changes this traditional communication pattern in the sense that any politician can set up a Twitter account and start spreading their news, which then can reach other parts of the public due to media coverage (Rogstad, 2016). Therefore, parties which are more divided on European integration should have MPs who, when sharing their true preference on Twitter, appear more distant from the party line on Twitter. The platform is used as a substitute channel

\footnotetext{
${ }^{2}$ In addition, journalists use Twitter as sources for stories (Ahmad, 2010; Broersma and Graham, 2013; Parmelee, 2014), so tweeting can serve a function of agenda-building.
} 
by rebellious MPs to circumvent partisan constrains from other arenas, and constitutes our first substitution hypothesis:

H5 Politicians' disagreement with their parties on Twitter about European integration is related to their parties' disunity on European integration.

Contrary to social media, partisan control of their MPs on the parliamentary arena is well documented. The model of legislative speech delegation by Proksch and Slapin (2012) proposes that party leaders have two considerations when deciding whether to give the parliamentary floor to an MP: communicating the party message, and giving exposure to individual backbencher MPs. Due to concerns with party unity, leaders are less likely to give speaking time in parliament to dissenting MPs. If H5 is correct and MPs do share their true positions on Twitter, allowing us to observe intra-party disagreements, then the disagreement shown there would allow us to predict that MPs who disagree with their parties' line about Europe on Twitter will speak less about Europe in parliament. This is our next substitution hypothesis:

H6 Politicians who show higher disagreement with their parties on Twitter about European integration speak less often in Parliament on Europe.

Nevertheless, even if party leaders are intent on enforcing unity, the legislative speech delegation model also recognizes leaders' incentive to give the floor to backbenchers for speeches to increase their exposure. From MPs' perspective, which value such exposure, it would be wise to deliver a speech close to the party line, in order to increase the chances of getting more time in the future (Proksch and Slapin, 2012). The model then proposes that when party leaders delegate speaking time to an MP, we may expect the speech to reflect a position located somewhere between the MP's true position on the issue and the party's ideal point. If the MP has the exact same position as the party, that is expressed, but if there is disagreement, then the speech may be a compromise between the MP's true preference (which we assume to be expressed on Twitter) and the party position. Even if H6 is true, MPs who disagree with their parties are not completely prevented from speaking in parliament. They would still deliver speeches, but the position expressed would be a compromise between their true position and the party position. For MPs whose true EU position (on Twitter) is very close to or the same as the party's, the position they express in parliament would then be the same or very close to their Twitter position. However, MPs whose EU position on Twitter is distant from their parties' would deliver speeches which are a compromise between their true preference (on Twitter) and the party preference. Therefore, we may expect that the EU position by MPs on Twitter and in parliament is more similar for those MPs who agree with their parties on Twitter, and less similar for those MPs who disagree with their parties on Twitter, because when given time to speak on the EU in parliament, they will have to move further away from their true (Twitter) EU position and toward their party's. Our last hypothesis therefore is:

H7 The relationship between MPs' EU position on Twitter and in Parliament is weaker for MPs who show high disagreement with their parties on Europe on Twitter.

\section{Twitter and parliamentary speech data and methods}

We base our analysis on an original dataset of Twitter activities by politicians in Europe from Castanho Silva and Proksch (2021), which includes all tweets posted by all members of national parliaments in seven EU countries in 2018: Denmark, France, Germany, Italy, Spain, Sweden, and the UK. We choose this country sample for two reasons. First, Twitter has a high adoption rate of on average 83 percent of MPs in this sample. Second, it was possible to obtain parliamentary 
speech records for all MPs in those countries and match these to their Twitter communication (partly based on the ParlSpeech v2 dataset by Rauh and Schwalbach, 2020). This yields an unprecedented dataset that allows us to compare individual political communication across arenas. Based on a list of all MPs from those countries in 2018, we used the streamR package for R (Barberá, 2018) to download in real time every tweet posted by every MP between 16 February and 31 December 2018, which at a later date was complemented with a historical search to capture tweets from 1 January 2018. The total database includes 2,088,383 tweets. ${ }^{3}$

Table 1 includes the breakdown of the data by country. Twitter is highly popular among politicians in these countries: the lowest adoption rate is 66 percent in Italy, while the highest is in France, where 95 percent of MPs have an account. British legislators are the most active, having tweeted 734,175 times in 2018, followed by Spanish and French. As shown in Table 1, we split the data from Spain into two samples due to the cabinet change in June, in which the then opposition Socialist Party took over the government from the ruling conservative Popular Party amid corruption scandals. ${ }^{4}$ Since governing status is related to the issues we study, such as intra-party dissent or positions expressed on Europe, all analyses treat each period separately.

We perform the following pre-processing steps to the Twitter data. First, we filter tweets to keep only those in the national languages or English. ${ }^{5}$ Second, we apply an EU-filter that includes a list of Twitter handles of official EU bodies and European political groups (as of 2018) and several EU-related keywords, translated into each of the seven languages. ${ }^{6}$ The keywords include terms such as "Brussels", "Europ" (or an equivalent stem), and the acronym of the EU in the respective language (say, "UE”, for "Unión Europea” in Spanish). ${ }^{7}$ In total, out of all MPs' tweets, 101,071 are identified as referring to Europe (around 4.8 percent) during 2018.

We conducted a hand-coding validation of this EU-dictionary. For each party, up to 100 tweets mentioning Europe were randomly selected, leading to a sample of 3408 tweets. Two student assistants coded whether those tweets mentioned Europe in a political way (1) or not (0). In total, 51 percent of the tweets were marked by both coders as referring to Europe in a political way or European integration, and 77 percent were marked so by at least one coder. The share of false-positive tweets, meaning both coders considered that the tweet did not refer to European politics, was 23 percent. $^{8}$ Hence, we control for potential bias in the measurement by including MPs' sentiment on all tweets which are not mentioning Europe in the models. This way, the variance in MPs' EU sentiment which is due to style-a component captured in the false positives-would be explained away, and the remaining variance is explained by EU position. A more detailed account of this validation is included in the online Appendix.

In addition to all Tweets by MPs in the seven countries, we collected all parliamentary speeches delivered between January and October 2018. ${ }^{9}$ In every country there are at least a few MPs who did not speak in parliament in 2018. The number of speeches varies greatly

\footnotetext{
${ }^{3}$ We focus on this period due to data availability, and consider that an entire year of tweets and speeches on a topic give us a good snapshot into how MPs communicate in these two arenas.

${ }^{4}$ There were no other cabinet changes within the dataset span in 2018 . We only use data from Italy after the March 04 elections, and from Sweden prior to the September legislative elections.

${ }^{5}$ The data streamed from Twitter have a column with the estimated language, used to filter. For around 5 percent of the sample, the estimated language was undetermined. Inspecting those tweets, most are either in Catalonian or tweets that contained nothing but a url link. These were also excluded from the analysis.

${ }^{6}$ The full list is in Table A.1 in the online Appendix.

${ }^{7}$ More specifically, the filtering process was to first subset the data into only tweets of a given language, and then filter EU tweets based on the EU-filter for that language alone. This way, if an MP tweeted in more than one language, the sentiment will be correctly estimated for each.

${ }^{8}$ Krippendorff's $\alpha$, however, was below usual thresholds, at 0.44 .

${ }^{9}$ For Italy, we only include those after the March 4, 2018 general elections. There were only two sessions of the prior Italian legislature in 2018 before March, and therefore we do not take those into account. For Sweden, collection stops at the September legislative elections.
} 
Table 1. Descriptive statistics of Twitter and parliamentary speech data for 2018

\begin{tabular}{lrrrrrrrr}
\hline & Denmark & France & Germany & Italy & Spain 1 & Spain 2 & Sweden & UK \\
\hline MPs & 206 & 586 & 709 & 629 & 351 & 351 & 436 & 650 \\
MPs on Twitter & 167 & 559 & 548 & 413 & 302 & 302 & 347 & 601 \\
Spoke in Parl. & 143 & 578 & 647 & 526 & 220 & 184 & 384 & 631 \\
Spoke on EU & 125 & 509 & 505 & 342 & 161 & 119 & 338 & 555 \\
Speeches & 17,807 & 159,770 & 13,369 & 19,548 & 2,220 & 1,675 & 18,693 & 54,190 \\
Speeches on EU & 1,838 & 5,771 & 2,184 & 1,138 & 491 & 295 & 3,690 & 6,745 \\
Tweets & 65,383 & 380,264 & 233,016 & 176,779 & 123,365 & 242,665 & 132,736 & 734,175 \\
Tweets EU & 2,634 & 27,936 & 14,495 & 9,854 & 4,462 & 8,912 & 3,763 & 29,015 \\
\hline
\end{tabular}

Spain 1 refers to the period until 1 June 2018, and Spain 2 is the period after. Spoke in Parl. is the number of MPs who spoke in parliament at least once in 2018; Spoke on EU is the number of MPs who gave at least one speech mentioning Europe in 2018. Speeches on EU refer to any speeches that mentioned Europe or any of the Europe-related keywords at least once.

between countries due to different parliamentary procedures and filing practices, ranging from fewer than 2000 in post-June Spain to almost 160,000 in France, as indicated in Table 1. We apply the same EU-dictionary to find speeches that mention Europe or the EU at least once. We find that the share of Europe-related speeches ranges between 4 percent (France) and 20 percent (Spain).

\subsection{Measuring positions on Europe on twitter}

We adopt a text-based approach to estimating and comparing MPs' positions on Twitter and parliamentary speech. We use a domain-specific sentiment approach by applying a multilingual sentiment dictionary to EU-related tweets and excerpts of parliamentary speeches. We rely on automatic translations of the Lexicoder sentiment dictionary (Soroka, 2012; Young and Soroka, 2012; Proksch et al., 2019). This sentiment dictionary has previously been successfully applied to study newspaper content (e.g., Soroka, 2012; Young and Soroka, 2012; Soroka, 2014) and parliamentary speeches (Proksch et al., 2019). Most importantly, the dictionary has been translated into all EU languages by Proksch et al. (2019), therefore fitting our purposes of examining sentiment across several countries. ${ }^{10}$

Our goal is to calculate sentiment at the MP level, meaning we aggregate occurrences of positive and negative terms in all EU-related Tweets or parliamentary speeches for each individual MP, and calculate the sentiment based on those totals. ${ }^{11}$ We follow Proksch et al. (2019) and calculate sentiment as the logged ratio of positive to negative terms. A similar approach has been used by Heidenreich et al. (2020) to measure politicians' (anti)immigration views on Facebook, and yielded valid and reliable results.

Sentiment on the EU in parliamentary speech is calculated in an identical manner, following the approach by Rauh et al. (2020). We extract a text window of five words before and five words after the EU-related keyword occurrence and count the occurrences of the sentiment dictionary in those text windows. The aim is to assure that sentiment is measured in relation to an EU- or Europe-related mention. The positive and negative terms are then aggregated at the MP level, and sentiment calculated for each MP. ${ }^{12}$ Finally, to capture the intra-party dynamics on the issue of

\footnotetext{
${ }^{10}$ Proksch et al. (2019) used the Google Translate API to get automated translations of all the terms in this dictionary, and then had native speakers correct the German and French versions, in order to test the quality of automated translations. Results show that they are valid and reliable. The use of Google translate for text-as-data approaches that rely on a bag-of-words assumption has also been validated by de Vries et al. (2018).

${ }^{11} \mathrm{We}$ apply the usual text data cleaning processes of removing numbers and punctuation, and lowering the case for all terms. All analyses were conducted using the quanteda package for R, v. 2.0.1 (Benoit et al., 2018).

${ }^{12}$ Tables A.3-A.10 in the online Appendix show the 15 most used positive and negative dictionary terms in each country, for both Twitter and Parliament.
} 
European integration on Twitter, we use the absolute difference between the EU sentiment of an MP and their party average EU sentiment-higher differences between an MP and their party average sentiment on Europe on Twitter indicating higher disagreement on the issue. ${ }^{13}$

\subsection{Validating the measures}

We validate our sentiment-based measures at the party level using expert assessments from the Chapel Hill Expert Survey (CHES, Polk et al., 2017). ${ }^{14}$ First, we examine if the average sentiment of a party's MPs on tweets mentioning Europe is related to the CHES measure of EU integration preferences. Figure 1 shows these relationships across countries, and we observe a positive correlation in five of the seven countries. Parties with more positive EU sentiment on Twitter are the most pro-European in Denmark, France, Spain, Germany, and Sweden. The two exceptions are Italy and the UK. These are two countries with particular political contexts in 2018. In Italy, two of the most Euroskeptic parties formed a governing coalition in June 2018, and it has been observed that ruling parties tend to communicate with more positive sentiment than opposition ones (Proksch et al., 2019). Therefore, the fact that the League and the Five Star Movement have similar sentiment to the Democratic Party and Berlusconi's Forza Italia may be explained by the former being in government and thus adopting more positive discourse in general than they would otherwise. We therefore control for government membership in all subsequent analyses. Regarding the UK, we observe a situation which may produce statements where sentiment on EU-related matters is not expressed vis-á-vis the EU, but with regard to the British government's stance of dealing with Brexit. Thus, the reversal of the relationship suggests that, by and large, sentiment reflects pro-European criticism of the way the government was handling the negotiations. While we keep the UK in our sample for the analyses in the study, we both add a random effect for the UK in the models explaining sentiment, and run robustness tests of all models dropping out the UK in the online Appendix. ${ }^{15}$

The right-hand panel of Figure 2 shows that, on aggregate, this correlation also appears in parliament: parties whose members use more positive sentiment when referring to Europe in parliament are also those which experts rate as more in favor of European integration. Figure A.5 in the online Appendix shows the relationship by country and party, which presents the same pattern as the Twitter sentiment estimates: strong positive correlations for all countries other than UK and Italy. The left panel in Figure 2 looks at whether parties that mention the EU more in their tweets care more about the issue according to the experts. There is a positive correlation with $r=0.53$. The more a party tweets about Europe, indicated by the Europe keywords, the more salient EU integration is for that party according to experts. ${ }^{16}$

Next, we validate if parties for which MPs have a higher average distance in sentiment to the party average are also those with more internal dissent on European integration in Figure $3 .{ }^{17} \mathrm{We}$ find a positive relationship in all countries other than Spain. For almost all countries, parties whose MPs have a larger distance in sentiment on EU tweets to their parties' averages are also those which experts judge to be the most divided on European integration. Table A.2 in the

\footnotetext{
${ }^{13}$ The distributions of this variable and of sentiment on EU tweets across countries are in Figure A.1 in the online Appendix.

${ }^{14}$ For all countries which were part of the 2017 Flash CHES, whose surveys were fielded in January and February 2018, we used that version, since they were contemporary to the period of the tweets and speeches in this study. For Denmark, which was not part of the 2017 CHES, and the Swedish party Liberalerna, which was not covered in 2017, we used the most recent 2019 version.

${ }^{15}$ All results remain the same or become stronger.

${ }^{16}$ We use the log number of tweets, since it is a very skewed variable. If we use the raw count, the correlation is $r=0.38$. Figure A.4 in the online Appendix shows this relationship by country and party.

${ }^{17}$ We restrict this plot to parties with at least three members tweeting about Europe, otherwise there are too few to investigate MPs' distances to the party average.
} 

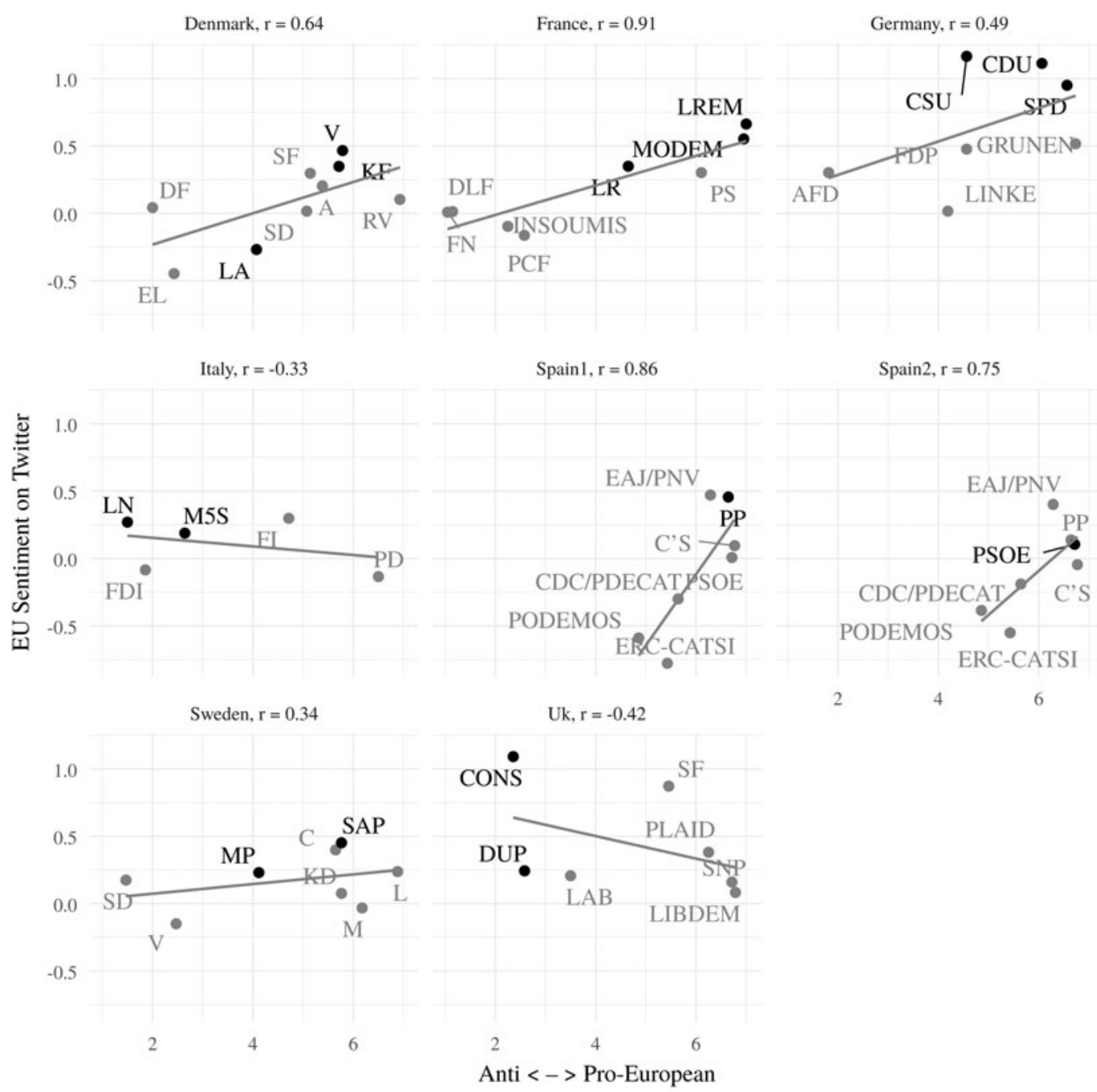

- Government $\quad$ Opposition

Fig. 1. EU position (CHES) and EU sentiment on Twitter by parties and countries. Note: In Spain, the PP was in government up to June, and the PSOE after.

online Appendix shows a list of all MPs who have a distance to their parties higher than 2, meaning those that are the most distant from their party average.

Our final validation procedure involves a comparison of automated sentiment of tweets and manually coded sentiment. To do so, we draw random samples of $20 \mathrm{EU}$ tweets for all German and British political parties (seven parties in each country, leading to $140 \mathrm{EU}$ tweets per country in total). Two sets of student assistants fluent on the respective languages coded each tweet on a 1-5 Euroskepticism scale. ${ }^{18}$ At the individual tweet level, the correlation between sentiment and the hand-coded Euroskepticism measure is $r=-0.38$ in Germany. This correlation

\footnotetext{
${ }^{18}$ The wording of the instructions was: "On a scale where 1 represents a very Europhile position, 3 is neutral, and 5 is a very Euroskeptic position, where would you place the idea conveyed by this tweet? Here, Euroskepticism is broadly defined as aversion toward EU institutions and (further) EU integration." Krippendorff s $\alpha$ was 0.60 for both countries.
} 
EU Tweets and Salience

$\mathrm{r}=0.53$

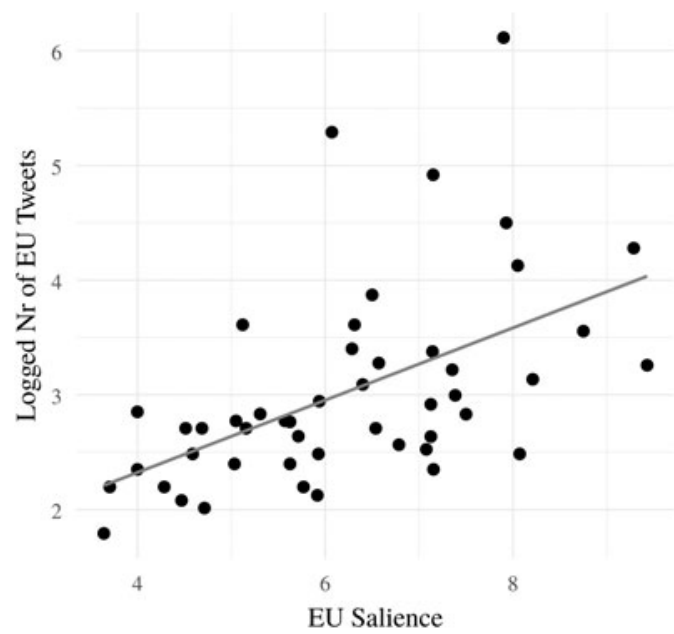

EU Position and Sentiment in Parliament

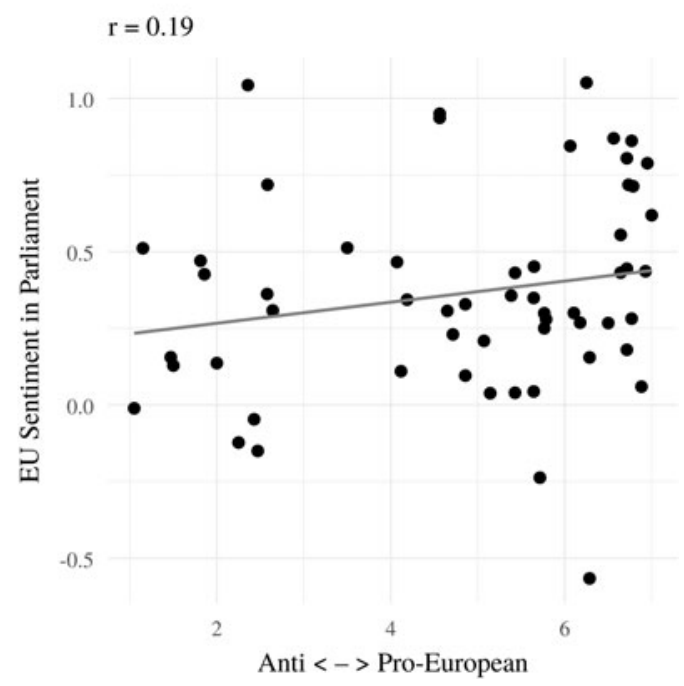

Fig. 2. Party-level correlation between salience, position, and CHES measures.

suggests more negative tweets are also coded more Euroskeptic by the coders. For the UK, on the other hand, the confusion between sentiment and government status appears also in the hand coding: the correlation between sentiment estimates and students' assessment of Euroskepticism of tweets is $r=0.04$, showing that there is more noise at capturing MPs' EU position there. As the sentiment is used as a dependent variable in our subsequent analysis, we control for overall sentiment and government status in order to capture these potential issues, along with fixed effects to control for differences across countries, so that any remaining measurement error should be randomly distributed and only lead to larger standard errors for independent variables, thus biasing our analysis against finding relationships.

To illustrate the intra-party division, on the other hand, we need to look no further than the Conservative Party in Britain. The party average is very positive, at 1.09. It reflects the positive tone that then Prime Minister Theresa May and her faction used to discuss Europe, in the context of praising their proposals for a Brexit Withdrawal agreement. May's own sentiment on EU tweets is above the party average, at 1.56 . On the other side is Jacob Rees-Mogg, a contemporary Tory leader who in 2018 was very critical of then Prime Minister's May approach to Brexit. His average sentiment on tweets mentioning Europe is exactly 0, much below the party average. Therefore, even if the sentiment measure itself may be noisy for measuring EU position in the UK, the distance to the party does indicate disunity on the topic.

\section{Analysis and results}

We test our hypotheses with linear regressions with robust standard errors clustered by party, and with legislature-dummy fixed effects. ${ }^{19}$ They include typical legislative and party behavior indicators as control variables. At the individual MP level, we include the number of terms in parliament an MP has served, their gender, and if they ever held a ministerial position. These variables indicate the level of seniority and belonging to the political establishment. ${ }^{20}$ We also

\footnotetext{
${ }^{19}$ We use one dummy per country and two dummies for Spain, one for before and one for after June, reason why they are called legislature-dummies and not country-dummies.

${ }^{20}$ Data come from the Wikidata and Wikipedia pages of individual MPs.
} 


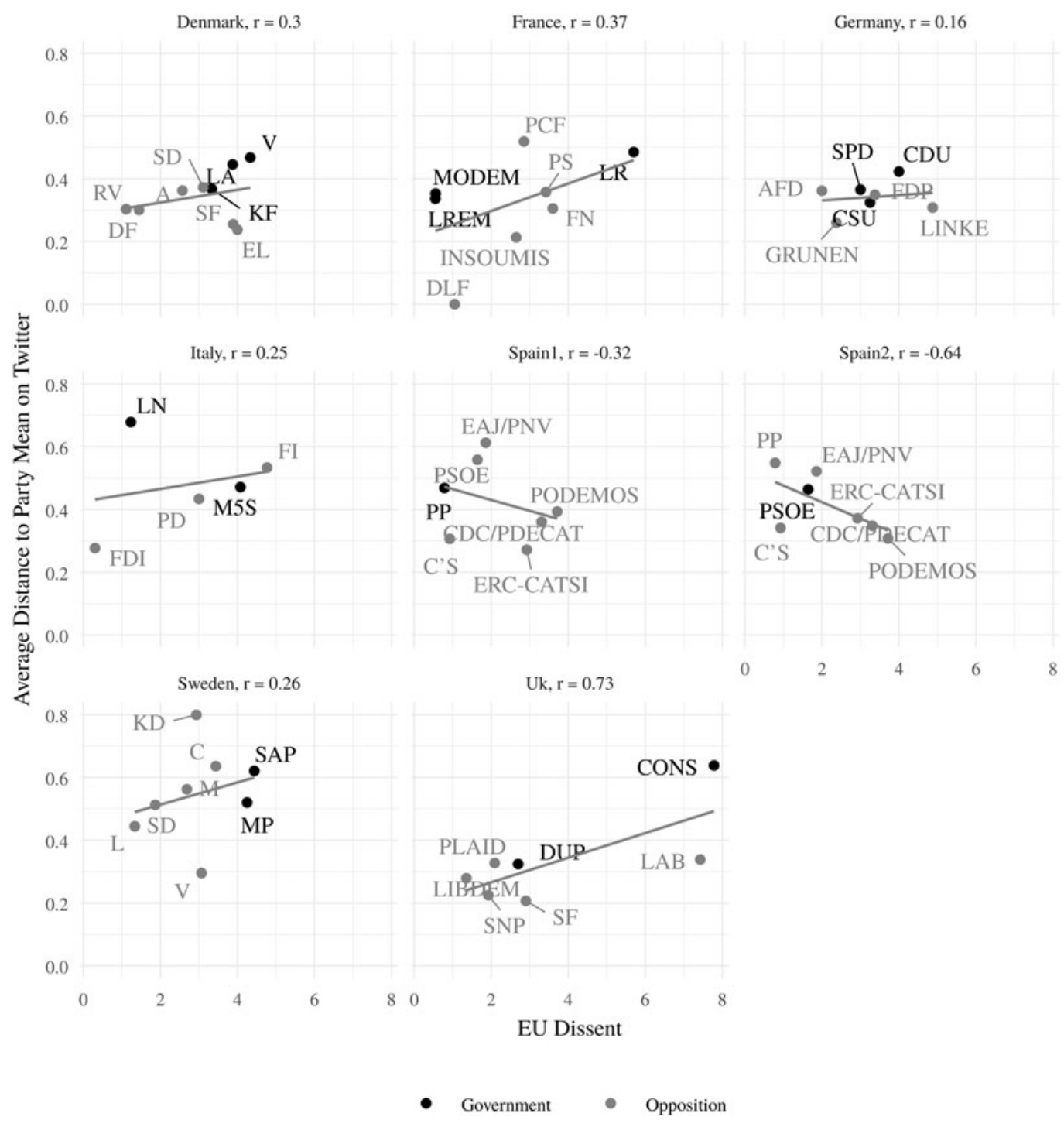

Fig. 3. EU dissent (CHES) and average distance to party mean EU sentiment on Twitter by parties and countries.

include a dummy for whether the MP holds a leadership position within the party-defined as being party-leader, deputy, or parliamentary group leader. At the party level, we consider the overall party left-right ideology from CHES, the party seat-share in parliament, and whether it was in government or opposition, using data from the ParlGov dataset (Döring and Manow, 2018).

\subsection{Amplifier mechanism}

Models testing the amplifier hypotheses are in Table 2. In Model 1, we see that MPs' EU sentiment on Twitter is predicted by their parties' EU position as judged by experts. Next, Model 2 shows that MPs' EU sentiment on Twitter has a positive and significant relationship with EU 
Table 2. Twitter as an amplifier channel

\begin{tabular}{|c|c|c|c|c|}
\hline & \multicolumn{2}{|c|}{ DV: EU sentiment on twitter } & \multicolumn{2}{|c|}{ DV: No. of EU tweets } \\
\hline & Model 1 & Model 2 & Model 3 & Model 4 \\
\hline Intercept & $\begin{array}{l}-0.48^{\star} \\
{[-0.71 ;-0.25]}\end{array}$ & $\begin{array}{l}-0.39^{*} \\
{[-0.64 ;-0.14]}\end{array}$ & $\begin{array}{l}-3.06^{*} \\
{[-3.47 ;-2.64]}\end{array}$ & $\begin{array}{l}-2.91^{*} \\
{[-3.33 ;-2.50]}\end{array}$ \\
\hline EU position & $\begin{array}{l}0.04^{*} \\
{[0.01 ; 0.07]}\end{array}$ & $\begin{array}{l}0.03 \\
{[-0.00 ; 0.05]}\end{array}$ & $\begin{array}{l}0.04^{*} \\
{[0.00 ; 0.07]}\end{array}$ & $\begin{array}{l}0.05^{*} \\
{[0.01 ; 0.08]}\end{array}$ \\
\hline Sentiment overall & $\begin{array}{l}0.51^{*} \\
{[0.38 ; 0.65]}\end{array}$ & $\begin{array}{l}0.46^{*} \\
{[0.31 ; 0.61]}\end{array}$ & & \\
\hline EU sentiment (Parl) & & $\begin{array}{l}0.07^{*} \\
{[0.03 ; 0.11]}\end{array}$ & & \\
\hline EU salience & & & $\begin{array}{l}0.13^{\star} \\
{[0.08 ; 0.18]}\end{array}$ & $\begin{array}{l}0.12^{\star} \\
{[0.07 ; 0.16]}\end{array}$ \\
\hline N. Tweets (log) & & & $\begin{array}{l}0.77^{\star} \\
{[0.71 ; 0.82]}\end{array}$ & $\begin{array}{l}0.75^{\star} \\
{[0.70 ; 0.80]}\end{array}$ \\
\hline N. of EU speeches & & & & $\begin{array}{l}0.18^{*} \\
{[0.14 ; 0.22]}\end{array}$ \\
\hline Terms in office & $\begin{array}{l}0.01 \\
{[-0.01 ; 0.03]}\end{array}$ & $\begin{array}{l}0.00 \\
{[-0.02 ; 0.02]}\end{array}$ & $\begin{array}{l}0.03^{*} \\
{[0.00 ; 0.07]}\end{array}$ & $\begin{array}{l}0.02 \\
{[-0.01 ; 0.06]}\end{array}$ \\
\hline Male & $\begin{array}{l}-0.02 \\
{[-0.08 ; 0.04]}\end{array}$ & $\begin{array}{l}-0.01 \\
{[-0.08 ; 0.06]}\end{array}$ & $\begin{array}{l}0.16^{\star} \\
{[0.08 ; 0.23]}\end{array}$ & $\begin{array}{l}0.13^{\star} \\
{[0.05 ; 0.20]}\end{array}$ \\
\hline Cabinet experience & {$\left[\begin{array}{l}0.01 \\
{[-0.08 ; 0.11]}\end{array}\right.$} & $\begin{array}{l}0.04 \\
{[-0.07 ; 0.15]}\end{array}$ & $\begin{array}{l}0.10^{\star} \\
{[0.00 ; 0.20]}\end{array}$ & $\begin{array}{l}0.02 \\
{[-0.07 ; 0.11]}\end{array}$ \\
\hline Party leader & $\begin{array}{l}0.02 \\
{[-0.10 ; 0.15]}\end{array}$ & $\begin{array}{l}0.02 \\
{[-0.11 ; 0.14]}\end{array}$ & $\begin{array}{l}0.18^{\star} \\
{[0.01 ; 0.36]}\end{array}$ & $\begin{array}{l}0.06 \\
{[-0.13 ; 0.26]}\end{array}$ \\
\hline Party in government & $\begin{array}{l}0.17^{\star} \\
{[0.09 ; 0.24]}\end{array}$ & $\begin{array}{l}0.22^{*} \\
{[0.14 ; 0.30]}\end{array}$ & $\begin{array}{l}0.03 \\
{[-0.10 ; 0.16]}\end{array}$ & $\begin{array}{l}0.02 \\
{[-0.12 ; 0.16]}\end{array}$ \\
\hline Seat share & $\begin{array}{l}0.14 \\
{[-0.20 ; 0.48]}\end{array}$ & $\begin{array}{l}0.11 \\
{[-0.15 ; 0.36]}\end{array}$ & $\begin{array}{l}-0.66^{\star} \\
{[-1.10 ;-0.22]}\end{array}$ & $\begin{array}{l}-0.41 \\
{[-0.85 ; 0.03]}\end{array}$ \\
\hline Party left-right & $\begin{array}{l}0.03^{\star} \\
{[0.01 ; 0.05]}\end{array}$ & $\begin{array}{l}0.02^{*} \\
{[0.01 ; 0.04]}\end{array}$ & $\begin{array}{l}0.01 \\
{[-0.02 ; 0.03]}\end{array}$ & $\begin{array}{l}0.01 \\
{[-0.01 ; 0.03]}\end{array}$ \\
\hline UK & $\begin{array}{l}0.55^{\star} \\
{[0.27 ; 0.83]}\end{array}$ & $\begin{array}{l}0.43^{*} \\
{[0.13 ; 0.73]}\end{array}$ & & \\
\hline EU position * UK & $\begin{array}{l}-0.09^{\star} \\
{[-0.14 ;-0.04]}\end{array}$ & $\begin{array}{l}-0.07^{\star} \\
{[-0.11 ;-0.03]}\end{array}$ & & \\
\hline Adj. $R^{2}$ & 0.29 & 0.32 & 0.75 & 0.76 \\
\hline Num. obs. & 2366 & 1720 & 2645 & 2645 \\
\hline$N$ Parties & 48 & 48 & 48 & 48 \\
\hline
\end{tabular}

* 0 outside the $95 \%$ confidence interval. Robust standard errors clustered at the party level. Legislature-dummy fixed effects beyond the UK included in models but not reported here. Sentiment overall: sentiment on all other tweets not mentioning Europe; EU position: party position on European integration (CHES); EU sentiment (Parl): MPs' sentiment around Europe-related keywords in their parliamentary speeches; EU salience: party salience of European integration (CHES); N. of EU speeches: number of speeches in parliament by the MP mentioning Europe; $\mathrm{N}$. all tweets (log): number of tweets sent by the MP in 2018; Terms in office: number of terms served by the MP in parliament; Cabinet experience: whether the MP was ever a cabinet member; Party leader: whether the MP is party leader; Party in government: whether the party is part of the governing coalition; Seat share: party seat share in parliament; Party left-right: party position on the general left-right scale (CHES).

sentiment in parliament, also after controlling for their parties' EU position. ${ }^{21}$ Importantly, we notice that the strongest coefficient in Models 1 and 2 are for the sentiment in MPs' tweets which do not refer to Europe, indicating that the EU variables are explaining variance even after personal style and tone are accounted for. These two models give evidence in favor of $\mathrm{H} 1$ and $\mathrm{H} 2$, indicating that sentiment on EU-related tweets does relate to other measures of position on the EU by parties and legislators. This way, MPs generally use Twitter to broadcast a message similar to that which they and their parties communicate in other media.

\footnotetext{
${ }^{21}$ Models 1 and 2 include an interaction between the UK dummy and EU position due to the unique effect of Brexit on British EU sentiment on Twitter.
} 
The second set of models tests the salience aspect of the amplifier mechanism. The dependent variable is the logged number of tweets mentioning Europe. ${ }^{22}$ Here, parties' EU salience is a significant predictor of MPs tweeting more about Europe (Models 3 and 4). And, in Model 4, the number of EU speeches by an MP in parliament shows a positive significant relationship with the number of tweets the MP posts mentioning Europe. These findings lend support to Hypotheses 3 and 4, whereby MPs who care more about Europe, or belong to parties which attribute more salience to the EU as an issue, do tweet more about it. Moreover, these results hold even though we control for the overall logged number of tweets posted by MPs, which naturally is a strong predictor of the number of EU-related tweets since it accounts for MPs' general level of online activity.

\subsection{The substitution mechanism}

The substitution mechanism is tested in Table 3. In Models 5 and 6 the dependent variable is MPs' distance in EU sentiment to their party's average EU sentiment on Twitter, to capture intraparty dissent on Twitter on the EU. Model 5 shows that this measure is significantly predicted by the CHES measure of EU dissent, whereby parties which are rated by experts as being more divided on European integration have MPs with more distance to the parties' average sentiment on Twitter, in line with the expectation of H5. Model 6 shows that the number of EU speeches in parliament, however, is negatively related to the distance to the party on Twitter: meaning, the less an MP talks about Europe in parliament, the more distance we observe between them and their parties on Europe-related tweets. This is evidence in favor of H6, suggesting that MPs who disagree more with their parties on Europe on Twitter-which can be interpreted as a measure of their general disagreement with their parties on this issue-tend to speak less about Europe in parliament, where party leaders have more control of who takes the floor.

Finally, Models 7 and 8 test the final hypothesis H7. The dependent variable is EU-related sentiment in parliament, and Model 7 is a reformulation of Model 2, from Table 2: EU sentiment on Twitter is significantly related to EU sentiment in parliament. Model 8, however, shows that there is a significant interaction with MPs' distance to their parties on Twitter, which is visualized in Figure 4: for MPs whose sentiment on Europe is very close to that of their parties on Twitter, the correlation between their EU sentiment on Twitter and in parliament is the highest. However, for MPs whose sentiment differs from their parties about the EU on Twitter, their discourse varies more across the two arenas. This is evidence in favor of MPs having to adjust their position in parliament and toeing more of a party line when giving speeches.

\section{Robustness and limitations}

A number of robustness tests are shown in the online Appendix. First, we run the models from Tables 2 and 3 excluding the UK, since the relationship between sentiment and EU position there seems to be reversed. All results hold and the estimated effects tend to be larger. Second, given that there are different numbers of MPs in each country, we run all models reweighing the observations by the inverse of the proportion of each country in the total number of MPs, so that those from countries with smaller chambers (such as Denmark) receive higher weights. Results remain the same. Third, we run those models excluding MPs who tweeted fewer than five times about Europe in 2018. With very few tweets, there might be more measurement error in estimating their positions. While this reduces the sample size and statistical power, significant results remain the same. Fourth, we run the models from Table 3 separately in each country. Both the main coefficients of sentiment, and the interaction, are almost never significant, due to substantially smaller samples, but still pointing in the same direction in five of the eight legislatures considered. Fifth, we run Models 7 and 8 from Table 3 with larger windows of words before and after the occurrence of a Europe-related keyword in speeches to estimate sentiment. Sentiment is captured with 15 and 30 words before/after the keyword (as

\footnotetext{
${ }^{22} \mathrm{We}$ take the $\log$ due to the skewed nature of this variable.
} 
Table 3. Twitter as a substitute channel

\begin{tabular}{|c|c|c|c|c|}
\hline & \multicolumn{2}{|c|}{$\begin{array}{c}\text { DV: distance to average party EU } \\
\text { sentiment (Twitter) }\end{array}$} & \multicolumn{2}{|c|}{ DV: EU sentiment in parliament } \\
\hline & Model 5 & Model 6 & Model 7 & Model 8 \\
\hline Intercept & $\begin{array}{l}0.22^{\star} \\
{[0.08 ; 0.37]}\end{array}$ & $\begin{array}{l}0.23^{\star} \\
{[0.08 ; 0.38]}\end{array}$ & $\begin{array}{l}-0.28^{\star} \\
{[-0.54 ;-0.02]}\end{array}$ & $\begin{array}{l}-0.25 \\
{[-0.49 ; 0.00]}\end{array}$ \\
\hline EU dissent & $\begin{array}{l}0.02^{\star} \\
{[0.01 ; 0.03]}\end{array}$ & $\begin{array}{l}0.02^{\star} \\
{[0.01 ; 0.03]}\end{array}$ & & \\
\hline $\begin{array}{l}\text { Distance to party } \\
\text { (Twitter, non-EU) } \\
\text { N. of EU speeches }\end{array}$ & $\begin{array}{l}0.39^{\star} \\
{[0.27 ; 0.52]}\end{array}$ & $\begin{array}{l}0.39^{\star} \\
{[0.26 ; 0.52]} \\
-0.04^{\star} \\
{[-0.06 ;-0.02]}\end{array}$ & & \\
\hline EU sentiment (Tw) & & & $\begin{array}{l}0.18^{\star} \\
{[0.10 ; 0.25]}\end{array}$ & $\begin{array}{l}0.35^{\star} \\
{[0.24 ; 0.47]}\end{array}$ \\
\hline EU distance to party (Tw) & & & $\begin{array}{l}0.03 \\
{[-0.07 ; 0.13]}\end{array}$ & $\begin{array}{l}0.10 \\
{[-0.00 ; 0.21]}\end{array}$ \\
\hline $\begin{array}{l}\text { EU sentiment }(\mathrm{Tw})^{\star} \\
\text { EU distance to party }(\mathrm{Tw})\end{array}$ & & & & $\begin{array}{l}-0.14^{\star} \\
{[-0.21 ;-0.07]}\end{array}$ \\
\hline Terms in office & $\begin{array}{l}0.01 \\
{[-0.01 ; 0.02]}\end{array}$ & $\begin{array}{l}0.01 \\
{[-0.01 ; 0.02]}\end{array}$ & $\begin{array}{l}-0.02 \\
{[-0.04 ; 0.00]}\end{array}$ & $\begin{array}{l}-0.01 \\
{[-0.03 ; 0.00]}\end{array}$ \\
\hline Male & $\begin{array}{l}-0.01 \\
{[-0.06 ; 0.03]}\end{array}$ & $\begin{array}{l}-0.00 \\
{[-0.05 ; 0.04]}\end{array}$ & $\begin{array}{l}0.08 \\
{[-0.05 ; 0.21]}\end{array}$ & $\begin{array}{l}0.08 \\
{[-0.05 ; 0.21]}\end{array}$ \\
\hline Cabinet experience & $\begin{array}{l}-0.05^{\star} \\
{[-0.11 ;-0.00]}\end{array}$ & $\begin{array}{l}-0.03 \\
{[-0.08 ; 0.01]}\end{array}$ & $\begin{array}{l}0.04 \\
{[-0.11 ; 0.20]}\end{array}$ & $\begin{array}{l}0.03 \\
{[-0.12 ; 0.18]}\end{array}$ \\
\hline Party leader & $\begin{array}{l}-0.07 \\
{[-0.15 ; 0.00]}\end{array}$ & $\begin{array}{l}-0.05 \\
{[-0.12 ; 0.02]}\end{array}$ & $\begin{array}{l}-0.02 \\
{[-0.30 ; 0.27]}\end{array}$ & $\begin{array}{l}-0.02 \\
{[-0.31 ; 0.27]}\end{array}$ \\
\hline Party in government & $\begin{array}{l}0.03 \\
{[-0.02 ; 0.09]}\end{array}$ & $\begin{array}{l}0.04 \\
{[-0.02 ; 0.09]}\end{array}$ & $\begin{array}{l}0.18^{\star} \\
{[0.05 ; 0.30]}\end{array}$ & $\begin{array}{l}0.14^{\star} \\
{[0.02 ; 0.26]}\end{array}$ \\
\hline Seat share & $\begin{array}{l}0.14 \\
{[-0.03 ; 0.31]}\end{array}$ & $\begin{array}{l}0.10 \\
{[-0.08 ; 0.27]}\end{array}$ & $\begin{array}{l}0.04 \\
{[-0.37 ; 0.45]}\end{array}$ & $\begin{array}{l}-0.03 \\
{[-0.41 ; 0.35]}\end{array}$ \\
\hline EU position & $\begin{array}{l}-0.01 \\
{[-0.02 ; 0.01]}\end{array}$ & $\begin{array}{l}-0.01 \\
{[-0.02 ; 0.01]}\end{array}$ & $\begin{array}{l}0.06^{*} \\
{[0.03 ; 0.09]}\end{array}$ & $\begin{array}{l}0.05^{\star} \\
{[0.03 ; 0.08]}\end{array}$ \\
\hline Party left-right & $\begin{array}{l}0.02^{*} \\
{[0.01 ; 0.03]}\end{array}$ & $\begin{array}{l}0.02^{*} \\
{[0.01 ; 0.03]}\end{array}$ & $\begin{array}{l}0.03^{*} \\
{[0.00 ; 0.05]}\end{array}$ & $\begin{array}{l}0.02 \\
{[-0.00 ; 0.04]}\end{array}$ \\
\hline Adj. $R^{2}$ & 0.08 & 0.08 & 0.10 & 0.11 \\
\hline Num. obs. & 2366 & 2366 & 1720 & 1720 \\
\hline$N$ Parties & 48 & 48 & 48 & 48 \\
\hline
\end{tabular}

* 0 outside the $95 \%$ confidence interval. Robust standard errors clustered at the party level. Legislature-dummy fixed effects included but not reported here. EU dissent: how unified the party is on the EU (CHES); Distance to party (Twitter, non-EU): distance to average party sentiment on Twitter on tweets not mentioning Europe; N. of EU speeches: number of speeches in parliament by the MP mentioning Europe; EU sentiment (Tw): sentiment on tweets related to Europe; EU distance to party (Tw): MPs' distance to party average sentiment on Europe-related tweets; EU position: party position on European integration (CHES); Terms in office: number of terms served by the MP in parliament; Cabinet experience: whether the MP was ever a cabinet member; Party leader: whether the MP is party leader; Party in government: whether the party is part of the governing coalition; Seat share: party seat share in parliament; Party left-right: party position on the general left-right scale (CHES).

opposed to five, as done in the main analyses presented in the paper). All results hold, with coefficients of similar magnitude. Finally, we present regression diagnostics plots for all eight models.

We must mention a few potential limitations of our study. While we have made several efforts at validating our measure, it remains clear that automated sentiment on tweets that mention a keyword is an imperfect measure of MPs' position on Europe. As mentioned previously, and detailed in the online Appendix, the share of false positives (i.e., tweets identified as referring to Europe but which human coders find not to be) is not negligible; and the relationship between sentiment and actual positions is clearly moderated by contextual factors such as governing status or, in the British case, Brexit. For these reasons, while we believe this measure to be superior to any existing individual-level measures of MPs' positions on European integration, we urge researchers who plan to use it in future studies to carefully consider whether their country of interest might present a challenging context, and perform a careful manual validation. 


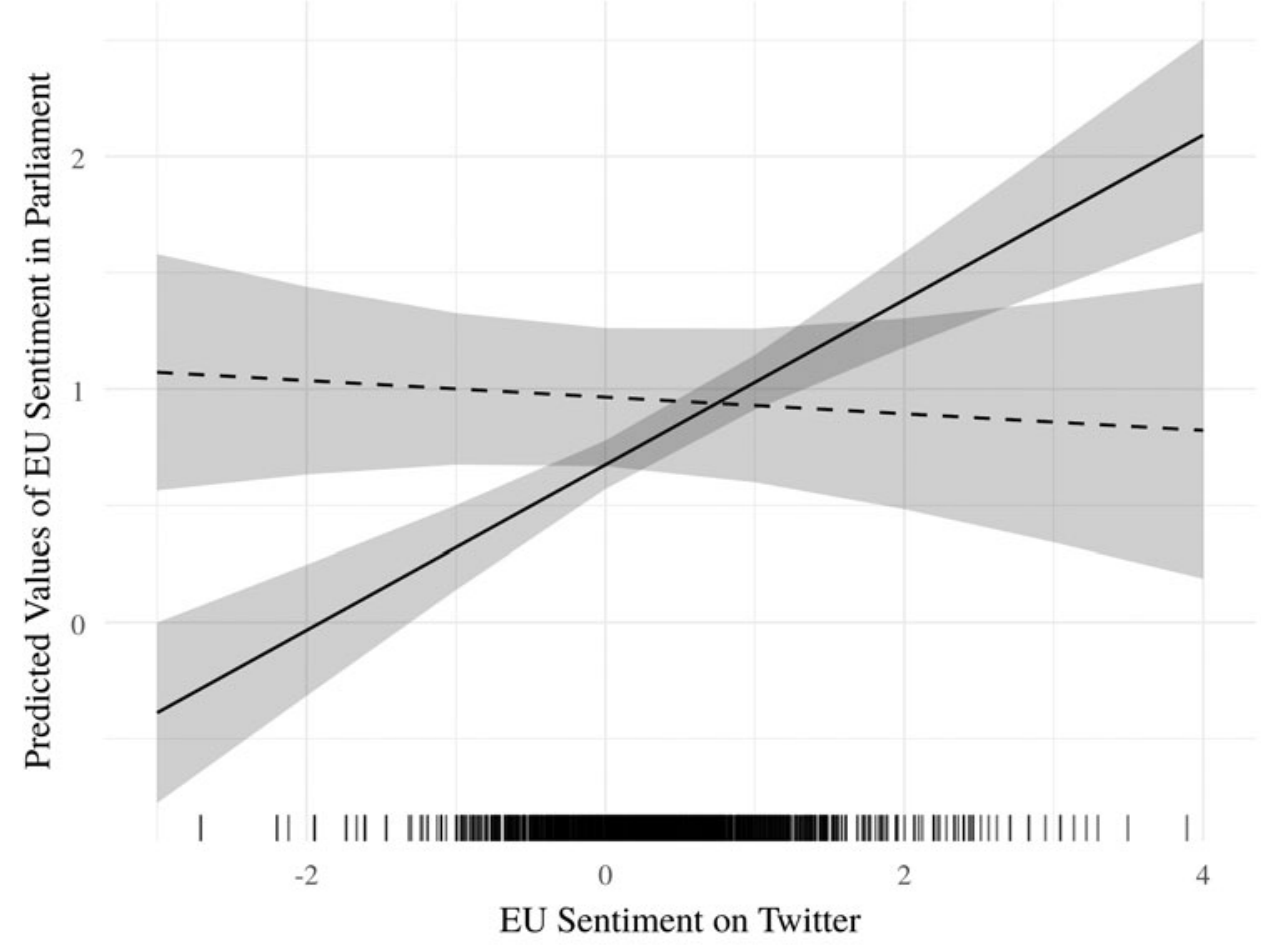

EU Distance to Party on Twitter

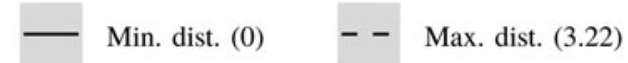

Fig. 4. Predicted values of EU sentiment in parliament-interaction between EU sentiment on Twitter and EU distance to party on Twitter.

\section{Conclusion}

Our findings shed new light on essential aspects of parliamentary politics and political communication. Social media in general, and Twitter in particular, offer members of parliament instant and individualized communication opportunities, raising the question whether they use it to amplify existing partisan rhetoric or to appear as unleashed party members offering their own discourse which may be at odds with the party. We find evidence that while MPs use Twitter to send a strong partisan message, some use it to express a broader range of opinions than in parliament. Specifically, our results suggest that MPs who participate less in parliamentary debate tend to have larger sentiment differences with their party on Twitter. Moreover, in the fewer instances where they do speak in parliament, we find that these dissidents express positions which are different to those they themselves express on Twitter, suggesting that perhaps even a certain level of self-censoring is taking place in the parliamentary arena. Even in systems where individual politicians are more independent from their party leadership, such as some countries included here like France, Denmark, or the UK, Twitter serves a strong substitute mechanism in European parliamentary systems.

In short, MPs do use Twitter to express their opinions even if that is against party lines, and parties cannot seem to control, as of now, what their MPs tweet. We find that Twitter can release politicians from the shackles of their parties. Some MPs take to Twitter to circumvent limitations on their speech imposed by partisan structures in other arenas, using Twitter as a substitute medium. From a measurement perspective, this finding contributes to the recent strand of 
literature trying to identify intra-party dissent through analysis of politicians' communication in various means (Ceron et al., 2019; Sältzer, 2020).

Our study furthermore presented a new way of measuring MP-level positions across different political arenas and countries. While there are multiple ways of measuring issue positions at the aggregate party level (e.g., expert surveys, analyses of manifestos, and so on), there are currently very few options one can use to measure issue positions of individual politicians, in a crossnational and comparative way. Using European integration as the example, we find that sentiment on Twitter is a useful measure for MPs' preferences on Europe. This has implications, for example, for any further research projects which would benefit from identifying individual MPs' preferences on a topic over time-going down to weekly or daily measures, in cases of very prolific Twitter users. Moreover, as we show in the last set of analyses on the substitution mechanism, individual MP level positions estimated from Twitter might be a closer match to their "true" preferences than those obtained from parliamentary speeches, where partisan controls affect if and how MPs speak.

As we mention, not every MP in Europe uses Twitter, and the variation in country-level adoption is indicative of systematic differences in usage. Our findings, therefore, are restricted to the set of MPs who are on Twitter, even though the vast majority of national MPs are active on social media. While we cannot claim a causal connection between rebellious behavior on Twitter and less chances to speak in parliament, we use disagreement on Twitter as a measure of intra-party dissent. Our study makes contributions on theoretical and methodological fronts, opening up several possibilities of future research on the use of social media by politicians in Europe. It is the first to link Twitter behavior by politicians to concrete, real-world consequences of their online action, shedding light on internal conflicts within political parties and how they affect parliamentary politics.

Supplementary material. The supplementary material for this article can be found at https://doi.org/10.1017/psrm.2021.36.

Acknowledgements. The authors acknowledge financial support from the Cluster "ECONtribute: Markets and Public Policy" funded by the Deutsche Forschungsgemeinschaft (DFG, German Research Foundation) under Germany's Excellence Strategy-EXC 2126/1-390838866.

\section{References}

Ahmad AN (2010) Is twitter a useful tool for journalists?. Journal of Media Practice 11, 145-155.

Barberá P (2015) Birds of the same feather tweet together: Bayesian ideal point estimation using twitter data. Political Analysis 23, 76-91.

Barberá P (2018) streamR: Access to Twitter Streaming API via R. R package version 0.4.3.

Benoit K, Watanabe K, Wang H, Nulty P, Obeng A, Müller S and Matsuo A (2018) quanteda: an r package for the quantitative analysis of textual data. Journal of Open Source Software 3, 774.

Bode L (2016) Political news in the news feed: learning politics from social media. Mass Communication and Society 19, 24-48.

Broersma M and Graham T (2013) Twitter as a news source. Journalism Practice 7, 446-464.

Carey JM (2009) Legislative Voting and Accountability. New York: Cambridge University Press.

Carey J and Shugart M (1995) Incentives to cultivate a personal vote: a rank ordering of electoral formulas. Electoral Studies 14, 417-439.

Castanho Silva B and Proksch S-O (2021) Fake it 'til you make it: a natural experiment to identify european politicians' benefit from twitter bots. American Political Science Review 115(1), 316-322.

Ceron A (2017) Intra-party politics in 140 characters. Party Politics 23, 7-17.

Ceron A, Curini L and Negri F (2019) Intra-party politics and interest groups: missing links in explaining government effectiveness. Public Choice 180, 407-427.

Cox G (2006) The organization of democratic legislatures. In Weingast B and Wittman D (eds), The Oxford Handbook of Political Economy. Oxford: Oxford University Press, pp. 141-161.

de Vries E, Schoonvelde M and Schumacher G (2018) No longer lost in translation: evidence that google translate works for comparative bag-of-words text applications. Political Analysis 26, 417-430. 
Diaz F, Gamon M, Hofman JM, Kıcıman E and Rothschild D (2016) Online and social media data as an imperfect continuous panel survey. PLoS ONE 11, 1-21.

Döring H and Manow P (2018) Parliaments and governments database (parlgov): information on parties, elections and cabinets in modern democracies. development version.

Ecker A (2017) Estimating policy positions using social network data: cross-validating position estimates of political parties and individual legislators in the polish parliament. Social Science Computer Review 35, 53-67.

Enli GS and Skogerbø E (2013) Personalized campaigns in party-centered politics. Information, Communication \& Society 16, 757-774.

Golbeck J, Grimes JM and Rogers A (2010) Twitter use by the u.s. congress. Journal of the Association for Information Science and Technology 61, 1612-1621.

Heidenreich T, Eberl J-M, Lind F and Boomgaarden H (2020) Political migration discourses on social media: a comparative perspective on visibility and sentiment across political facebook accounts in europe. Journal of Ethnic and Migration Studies 46, 1261-1280.

Hobolt SB and de Vries CE (2016) Public support for European integration. Annual Review of Political Science 19, 413-432.

Hobolt SB and Tilley J (2016) Fleeing the centre: the rise of challenger parties in the aftermath of the euro crisis. West European Politics 36, 971-991.

Hooghe L and Marks G (2018) Cleavage theory meets europe's crises: lipset, rokkan, and the transnational cleavage. Journal of European Public Policy 25, 109-135.

Jackson N and Lilleker D (2011) Microblogging, constituency service and impression management: Uk mps and the use of twitter. The Journal of Legislative Studies 17, 86-105.

Jungherr A, Schoen H and Jürgens P (2015) The mediation of politics through twitter: an analysis of messages posted during the campaign for the german federal election 2013. Journal of Computer-Mediated Communication 21, 50-68.

Kam CJ (2009) Party Discipline and Parliamentary Politics. New York: Cambridge University Press.

Kreiss D (2016) Seizing the moment: the presidential campaigns' use of twitter during the 2012 electoral cycle. New Media of Society 18, 1473-1490.

Kruikemeier S (2014) How political candidates use twitter and the impact on votes. Computers in Human Behavior 34, 131-139.

Larsson AO (2015) The eu parliament on twitter-assessing the permanent online practices of parliamentarians. Journal of Information Technology \& Politics 12, 149-166.

Parmelee JH (2014) The agenda-building function of political tweets. New Media \& Society 16, 434-450.

Polk J, Rovny J, Bakker R, Edwards E, Hooghe L, Jolly S, Koedam J, Kostelka F, Marks G, Schumacher G, Steenbergen M, Vachudova MA and Zilovic M (2017) Explaining the salience of anti-elitism and reducing political corruption for political parties in europe with the chapel hill expert survey data. Research \& Politics January-March, 1-9.

Popa SA, Fazekas Z, Braun D and Leidecker-Sandmann M-M (2020) Informing the public: how party communication builds opportunity structures. Political Communication 37, 329-349.

Proksch S-O and Slapin JB (2012) Institutional foundations of legislative speech. American Journal of Political Science 56(3), 520-537.

Proksch S-O and Slapin JB (2015) The Politics of Parliamentary Debate: Parties, Rebels, and Representation. Cambridge: Cambridge University Press.

Proksch S-O, Lowe W, Wäckerle J and Soroka S (2019) Multilingual sentiment analysis: a new approach to measuring conflict in legislative speeches. Legislative Studies Quarterly 44, 97-131.

Rauh C and Schwalbach J (2020) The parlspeech v2 data set: full-text corpora of 6.3 million parliamentary speeches in the key legislative chambers of nine representative democracies.

Rauh C, Bes BJ and Schoonvelde M (2020) Undermining, defusing or defending European integration? Assessing public communication of european executives in times of eu politicisation. European Journal of Political Research 59, $397-423$.

Rogstad I (2016) Is twitter just rehashing? Intermedia agenda setting between twitter and mainstream media. Journal of Information Technology \& Politics 13, 142-158.

Sältzer M (2020) Finding the bird's wings: dimensions of factional conflict on twitter. Party Politics, 1-10.

Schober MF, Conrad FG, Antoun C, Ehlen P, Fail S, Hupp AL, Johnston M, Vickers L, Yan HY and Zhang C (2015, 06) Precision and disclosure in text and voice interviews on smartphones. PLOS ONE 10, 1-20.

Sieberer U (2006) Party unity in parliamentary democracies: a comparative analysis. The Journal of Legislative Studies 12, $150-178$.

Soroka SN (2012) The gatekeeping function: distributions of information in media and the real world. Journal of Politics 74, $514-528$.

Soroka SN (2014) Negativity in Democratic Politics: Causes and Consequences. New York: Cambridge University Press.

Spierings N and Jacobs K (2014) Getting personal? The impact of social media on preferential voting. Political Behaviour 36, 215-234.

Stier S, Bleier A, Lietz H and Strohmaier M (2018) Election campaigning on social media: politicians, audiences, and the mediation of political communication on facebook and twitter. Political Communication 35, 50-74. 
Theocharis Y, Barberá P, Fazekas Z, Popa SA and Parnet O (2016) A bad workman blames his tweets: the consequences of citizens' uncivil twitter use when interacting with party candidates. Journal of Communication 66, 1007-1031.

Young L and Soroka SN (2012) Affective news: the automated coding of sentiment in political texts. Political Communication 29, 205-231.

Cite this article: Castanho Silva B, Proksch S-O (2022). Politicians unleashed? Political communication on Twitter and in parliament in Western Europe. Political Science Research and Methods 10, 776-792. https://doi.org/10.1017/psrm.2021.36 